\title{
AhR (Aryl Hydrocarbon Receptor) Polymorphisms: A Possible Role in TCDD (Dioxins)-AhR Binding and Carcinogenesis
}

\author{
Ruggero Ridolfi ${ }^{1}$, Rosaria Cozzolino ${ }^{2}$, Floriana Boscaino ${ }^{2}$, Luca Malorni ${ }^{3}$, Sergio Canzanella ${ }^{4}$, Antonio Malorni ${ }^{2}$, \\ Giuseppe Palmieri $^{5}$ \& Livia Malorni ${ }^{2}$ \\ ${ }^{1}$ Immunotherapy Unit, Istituto Scientifico Romagnolo per lo Studio e la Cura dei Tumori (IRST) IRCCS, \\ Meldola, Italy \\ ${ }^{2}$ Proteomic and Biomolecular Mass Spectrometry Center, Institute of Food Science and Technology (ISA), \\ National Research Council (CNR), Avellino, Italy \\ ${ }^{3}$ Oncology Unit "Sandro Pitigliani", Hospital of Prato, Prato, Italy \\ ${ }^{4}$ European Cancer Patient Coalition, House Hospital Onlus Association, Napoli, Italy \\ ${ }^{5}$ Unit of Cancer Genetics, Institute of Biomolecular Chemistry (ICB), National Research Council (CNR), Sassari, Italy \\ Correspondence: Ruggero Ridolfi, Immunotherapy Unit, Istituto Scientifico Romagnolo per lo Studio e la Cura dei \\ Tumori (IRST) IRCCS, 47014 Meldola (Forlì-Cesena), Italy. Tel: 39-0543-739-240. E-mail: \\ ruggero.ridolfi@gmail.com
}

Livia Malorni, Proteomic and Biomolecular Mass Spectrometry Center, Institute of Food Science and Technology (ISA), National Research Council (CNR), Via Roma 64, 83100 Avellino, Italy. Tel: 39-0825-299-111. E-mail: lmalorni@isa.cnr.it

Received: May 22, 2014 Accepted: June 25, 2014 Online Published: August 4, 2014

doi:10.5539/ijb.v6n4p82 URL: http://dx.doi.org/10.5539/ijb.v6n4p82

\begin{abstract}
Carcinogenicity of dioxins seems to be largely mediated by their binding to the aryl hydrocarbon receptor (AhR), a cytosolic transcriptional regulator of cell growth, differentiation, and migration. The most widely studied agonist of AhR, in the last thirty years, is 2,3,7,8-tetrachlorodibenzo-p-dioxin (TCDD), which also presents the highest binding affinity for this receptor. The activated ligand-AhR complex has been described to contribute in suppressing both humoral and cellular immune responses. Starting from the description of the main mechanisms underlying the physiological activation of $\mathrm{AhR}$, the present review is aimed at evaluating a putative functional role of the intragenic AhR polymorphisms, which could greatly affect the functionality of the receptor by either inducing or contrasting its ligand-dependent activation. As consequence, this may participate in lowering or increasing the risk of cancer, particularly, in the most polluted areas.
\end{abstract}

\section{Introduction}

The aryl hydrocarbon receptor (AhR), a cytosolic ligand-activated transcription factor, is a member of the PAS protein family and is highly conserved during the evolution, expressed in a variety of phylogenetically distant organisms such as drosophila melanogaster, nematodes, and mammals (Feng, Cao, \& Wang, 2013). The AhR protein acts as a transcriptional regulator of different biological aspects, with physiological functions mainly exerted during early stages of development of each organism. AhR is able to control neurogenesis, vascularization, circadian rhythms, metabolism, and stress responses to hypoxia, with evident effects on cell proliferation, differentiation, and migration (Hahn, 2002). Furthermore, AhR-mediated changes in gene expression frequently affect cell growth and regulate cell cycle progression (Elferink, 2003; Marlowe \& Puga, 2005; Glinka et al., 2012). In particular, induced Ahr signaling may either promote activiy of oncogenic kinases either interfere with the function of tumor suppressor genes (Falahatpisheh \& Ramos, 2003; Tomkiewicz et al., 2013).

The activated AhR has been widely studied in relation to its role in immunosuppression and a large amount of data has been published in this field (Stevens, Mezrich, \& Bradfield, 2009; Esser, Rannug, \& Stockinger, 2009). Activated AhR leads to a thymic involution, with consequent thymocyte loss and premature migration of $\mathrm{T}$ cell progenitors; it also suppresses T cell function and mediates B cell antibody response inhibition (Laiosa, 2003; Temchura, Frericks, Nacken, \& Esser, 2005; Ito, Inouye, Fujimaki, Tohyama, \& Nohara, 2002; Allan \& Sherr, 2005). The consequence is a profound suppression of both humoral and cellular immune responses (Stockinger, 
2009). Exposure of AhR to activating ligands either reduces the number and functions of $\mathrm{CD} 8^{+} \mathrm{T}$ cells either has an impact on dendritic cell (DC) phenotype, function, and quantity (Vorderstrasse, Dearstyne, \& Kerkvliet, 2003; Laupeze et al., 2002). In particular, AhR inhibits DC activation and differentiation, contributing to both reduce their number and block their maturation in mice and humans (Vorderstrasse \& Kerkvliet, 2001; Lee et al., 2007; Vogel et al., 2013; Aguilera-Montilla et al., 2013). Further important issues in activated-AhR-induced immunosuppression are the impact on the differentiation and expansion of both T- regulators $(\mathrm{CD} 4+\mathrm{CD} 25+$ FoxP3+) and IL-17-producing T helper cells (Th17 cells) with a consequent adverse effect on CD8+ T cell response (Funatake, Marshall, Steppan, Mourich, \& Kerkvliet, 2005; Quintana et al., 2008; Veldhoen et., 2008; Gandhi et al., 2010). The immunosuppressive action of dioxin-AhR binding is shown in Figure 1.

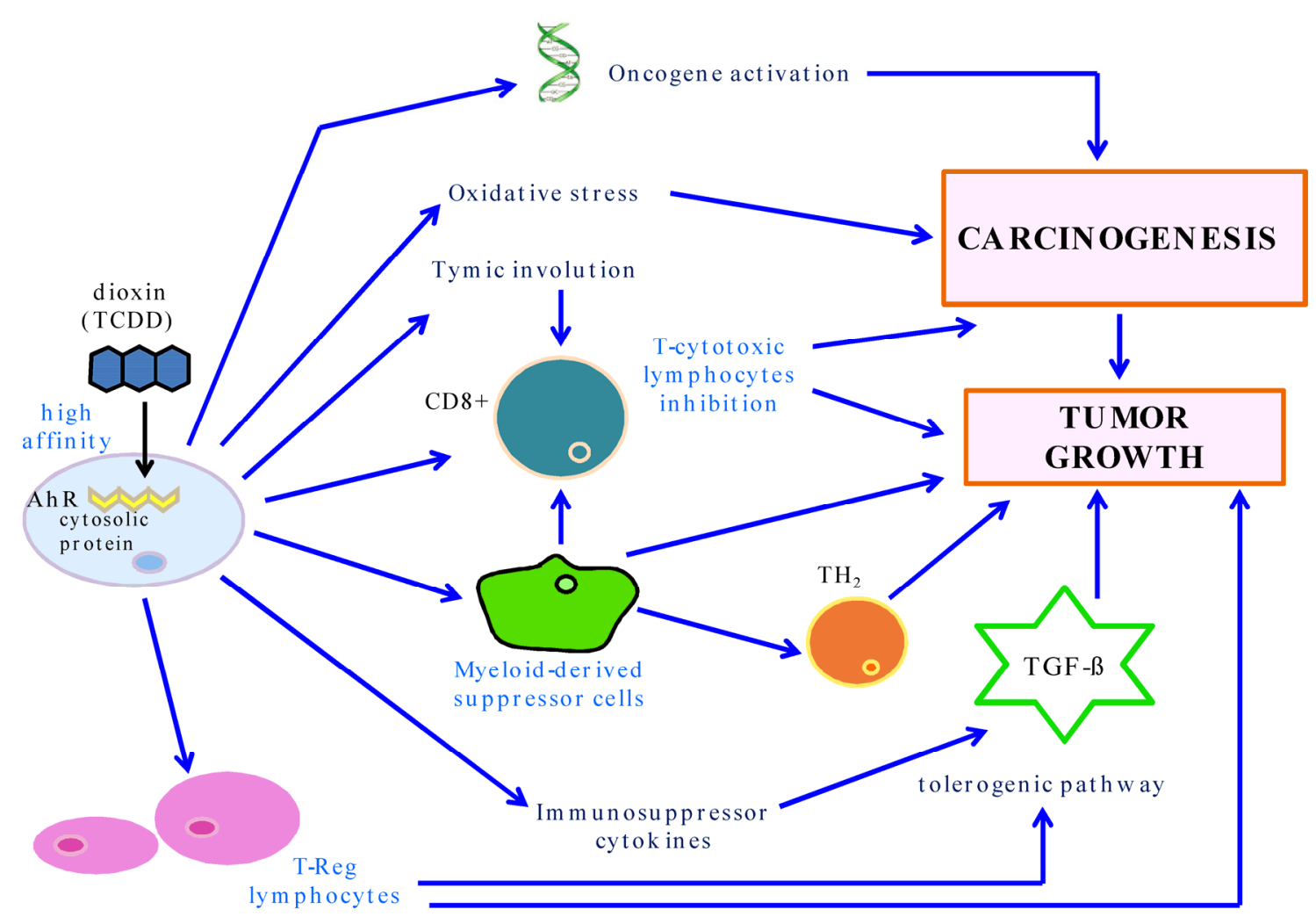

Figure 1. The immunosuppressive effects due to the TCDD-AhR binding activity

The AhR-driven immunosoppressive activity - together with the ancestral functions controlling cell differentiation, proliferation, and migration - is a strong indicator about the key role of this receptor in carcinogenesis (Quintana, 2013; Dietrich \& Kaina, 2010; Casado, Singh, \& Gasiewicz, 2011). An increasing amount of literature data indicates a strong association between high levels of activation of this receptor and cancer growth in preclinical models as well as cancer incidence (Di Natale, Schroeder, \& Perdew, 2011; John, Lahoti, Wagner, Hughes, \& Perdew, 2013; Tsay et al., 2013). The interaction between the activated AhR and estrogen receptor alpha has been described to play a positive role in E2-dependent BRCA-1 transcription, suggesting that impairment of BRCA-1 expression may contribute to the onset of breast cancers (Hockings et al., 2006). Recently a possible role of AhR has been reported in malignant B-cell growth as well as in tumor progression and metastasization when it is expressed in the melanoma stroma (Sherr \& Monti, 2013; Contador-Troca et al., 2013).

\subsection{AhR agonists}

In the last thirty years, the most widely studied agonist of AhR was 2,3,7,8-tetrachlorodibenzo-p-dioxin (TCDD) (Schecter, Birnbaum, Ryan, \& Constable, 2006), which exerts the highest binding affinity for this receptor: Stevens reports that in mice the $\mathrm{EC}_{50}\left(\mathrm{~mol} / \mathrm{kg}\right.$ ) for the TCDD-AhR binding is $10^{-12}$ (Stevens et al., 2009; Mimura \& Fujii-Kuriyama, 2003). TCDD and its congeners (Dioxins) are organochlorine compounds belonging to the families of polyalogenated-dibenzo-p-dioxin, polyalogenated-dibenzo-furan and polyalogenated-byphenyl; 
TCDD itself is listed as a class I carcinogen from the International Agency for Research on Cancer (IARC) Working Group (Tomatis, 2002). Dioxin molecules are extremely stable and spread rapidly through the environment, especially via the soil and water, inevitably polluting the food chain and accumulating in fatty tissues and milk of animals and humans as a result of their liposolubility (Schecter et al., 1994; Kerkvliet, 2002). Dioxins have a half-life in humans of 7 to 11 years, suggesting a potential accumulation within the body and a long-term stimulation and activation of AhR (Schecter et al., 1994, 2006; Bohonowych \& Denison, 2007). Recently, the IARC Working Group classified the polychlorinated biphenyls (PCBs) as a class I carcinogen, on the basis of extensive evidence of an AhR-mediated mechanism of carcinogenesis that is quite identical to that of TCDD. PCBs, a class of aromatic compounds, are persistent and readily absorbed. They also accumulate in the fatty tissues and are present in most samples of human milk (Lauby-Secretan et al., 2013).

\subsection{AhR Antagonists}

AHR binds several exogenous ligands such as natural plant flavonoids, polyphenolics, and indoles, but several other ligands with low to intermediate-affinity have been also described (Denison \& Nagy, 2003). Endogenous AhR ligands, e.g. low density lipoproteins and bilirubin, several dietary carotinoids and derivatives of tryptophan can be either antagonist or agonist, although they were generally considered as AhR antagonists because of their competitive action with respect to dioxin. For example, Savouret and colleagues identified 7-ketocholesterol (7-KC), an endogenous modulator that inhibits the AhR activation through competitive binding and displaces labeled dioxin (Savouret et al., 2001). Researchers have taken action for years to discover a good dietary candidate for preventing dioxin toxicity and major suggestions indicated several flavonoids (Ashida, Fukuda, Yamashita, \& Kanazawa, 2000). The anticarcinogenic effects of flavonoids (flavones, flavonols, and flavan-3-ols) include their antagonistic action on the AhR and experimental evidence suggests that flavonoids modulate signal transduction pathways at each stage of carcinogenesis (Mukai et al., 2010; Nishiumi et al., 2011). In the last ten years, several articles have demonstrated the molecular mechanisms by which food factors regulate the AhR activity and can suppress its transformation induced by dioxin. In particular, black tea, theaflavins, ethanolic extracts of propolis, and pigments in green tea leaves (Camellia sinensis) have been indicated as suppressor of dioxin-induced AhR activation; on the contrary, Anthocyans do not exert these properties. On this regard, several indigenous plants were described in Japan in 2006 (Nishiumi et al., 2006) and an update on the dietary ligands of the AhR was reported in 2008 (Ashida, Nishiumi, \& Fukuda, 2008). Papoutsis and colleagues described epigenetic mechanisms that may contribute to down-regulate the tumor suppressor gene BRCA-1 in breast cancers, through food compounds acting as AhR antagonists. The induction of BRCA-1 hypermethylation could be the basis for the development of prevention strategies aimed at silencing the TCDD-AhR activation (Papoutsis, Borg, Selmin, \& Romagnolo, 2012). Furthermore, an antiallergic drug (tranilast) that is an AhR agonist with inhibitory effects on triple-negative breast cancer cells selected for anti-cancer drug resistance has recently been discovered, suggesting promising applications in the treatment of such a disease (Prud'homme et al., 2010). Finally, epidemiological data indicated that flavonoids and proanthocyanidins seem to decrease the risk of cancer incidence. A series of Italian multicenter case-control studies (for a total of 16,000 controls and 10,000 incident cases of histologically-proven different cancer types) has indicated that the intake of these substances recognizes an inverse correlation with cancer incidence (Rossi, Bosetti, Negri, Lagiou, \& La Vecchia, 2010).

\subsection{Dioxins (TCDD), AhR, and Cancer}

Dioxin (TCDD) was classified as "carcinogenic to humans" (Group 1) in 1997 from the IARC; it is the first molecule for which "there is now sufficient epidemiological evidence for all cancers combined" (Baan et al., 2009). TCDD carcinogenicity is largely mediated by the AhR; among the different ligands, TCDD has indeed the highest affinity for this receptor (Stevens et al., 2009). However, many questions remain to be answered in order to understand the exact dynamics of these relationships. It is not clear how much the carcinogenicity of TCDD is linked to the action of AhR and/or mediated by the immune suppression. There are insufficient data about the concentration of Dioxins in adipose tissue (and, hence, plasma) in healthy subjects and in cancer patients, particularly within polluted areas. It is still unclear if the ability of protective factors (AhR antagonist) may inhibit or compete with dioxins in the AhR activation. Finally, data are missing about the capability of AhR to bind with its ligands in relation to the presence of genetic polymorphisms favoring or hampering such a binding. Here we tried to go through this last issue.

\section{Activation Mechanisms of AhR}

$\mathrm{AhR}$ is a ubiquitous cytosolic protein, highly conserved during evolution, which belongs to the family of "basic helix-loop-helix/Per-Arnt-Sim (bHLH/PAS)" transcription factors, presenting different functional domains (Figure 2). 


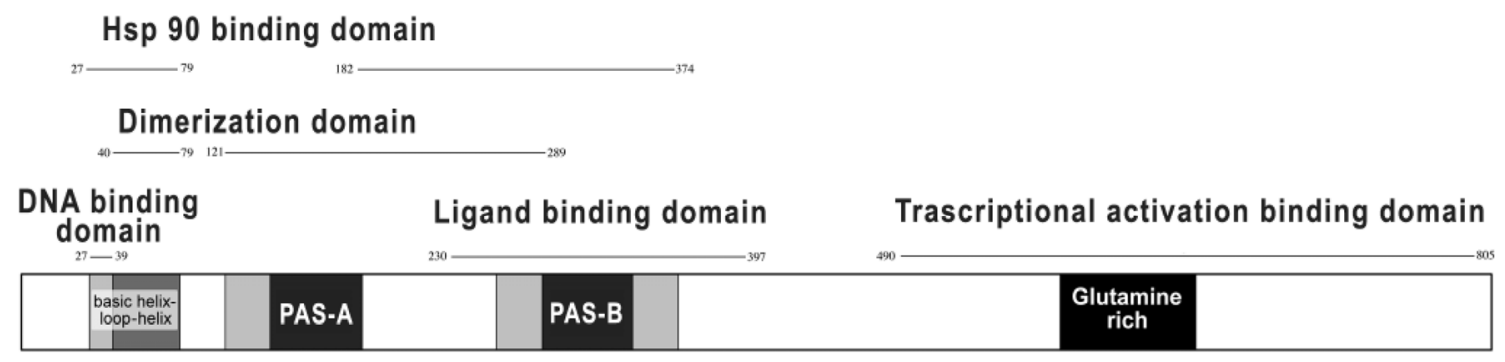

Figure 2. Main domains in the AhR protein

The bHLH motif is localized in the N-terminal region of the protein and is common in the transcription factors. The nuclear localization signal (NLS) sequence, which allows the transport of the protein inside the nucleus through the nuclear pore complex (NPC), is also present in the N-terminal region. Transport of the protein into the nucleus is dependent on cytosolic nuclear transport receptors, called importins (importin- $\alpha$ and importin- $\beta$ ), as well as a small monomeric GTPase, called Ran. Like other G proteins, Ran is active when bound to GTP and inactive when bound to GDP. In the cytosol, Ran is complexed with a protein called GAP (GTPase Activator Protein), which may promote its GTPase activity. In the nucleoplasm, Ran is instead complexed with GEF (Guanilic nucleotide Exchange Factor), a protein activating Ran through the induction of the GDP to GTP exchange. Therefore, a gradient of two conformational forms of Ran (Ran-GTP and Ran-GDP) can be generated across the two sides of the nucleus.

AhR functional domains, distinctive and highly conserved in this superfamily of receptors, are located: i) in the basic region, containing the DNA binding domain; ii) in the HLH region, which contains the helix-loop-helix motif, necessary for protein-protein interactions; iii) in two regions (PAS and PAS-A-B) presenting the dimerization (DD) and ligand-binding (LBD) domains, which specifically interact with other proteins containing PAS domains (Coumailleau, Poellinger, Gustafsson, \& Whitelaw, 1995; Goryo et al., 2007) or share a high homology with the domains of the following proteins: Per (period circadian protein), Sim (single-minded protein), and ARNT (aryl hydrocarbon receptor nuclear translocator protein) (Ema et al., 1992); iv) in the glutamine-rich C-terminal region, which contains the transactivation domain for the recruitment of co-activators (Kumar, Ramadoss, Reen, Vanden Heuvel, \& Perdew, 2001) (Figure 2).

In humans, the AhR gene maps at chromosome 7, spanning a genomic region of $47146 \mathrm{nt}$, and consists of 11 coding exons specifying for an mRNA of $5483 \mathrm{nt}$ (Micka et al., 1997). The AhR gene consists of $2547 \mathrm{nt}$ and encodes for a protein of 848 amino acid residues (Le Beau et al., 1994; Ema et al., 1994; Micka et al., 1997; http://www.uniprot.org/uniprot/P35869). The AhR protein is located in an inactive form in the cytosol, where it forms a multi-protein complex with the HSP90 (90-kDa Heath Shock Protein) chaperone (Denis, Cuthill, Wikström, Poellinger, \& Gustafsson, 1998; Perdew , 1998), the P23 (tubulin binding protein) co-chaperone (Cox \& Miller, 2004; Kazlauskas, Poellinger, \& Pongratz, 1999), and a subunit of XAP-2 (hepatitis B virus $\mathrm{X}$-associated protein or immunophilinlike protein), also referred to as AIP or ARA9 (Meyer, Pray-Grant, Vanden Heuvel, \& Perdew, 1998).

Such a multimeric complex is assembled through several stages. The initial AhR-HSP90 complex is stabilized by the intervention of $\mathrm{P} 23$ before binding the ligand (TCDD), which enters the cell by simple diffusion due to its high lipophilicity (Gu, Hogenesch, \& Bradfield, 2000) and binds to the receptor pocket of the PAS-B domain of AhR. The resulting ligand-AhR-HSP90-P23 complex is the pre-requisite for the recruitment of XAP-2, whose function is to redistribute the complex into the cell cytoplasm. After the complex formation, HSP90 induces a conformational change in the N-terminal portion of AhR, making its NLS sequence accessible to the importin- $\alpha$ (Kazlauskas, Sundstrom, Poellinger, \& Pongratz, 2001) (Figure 3). 


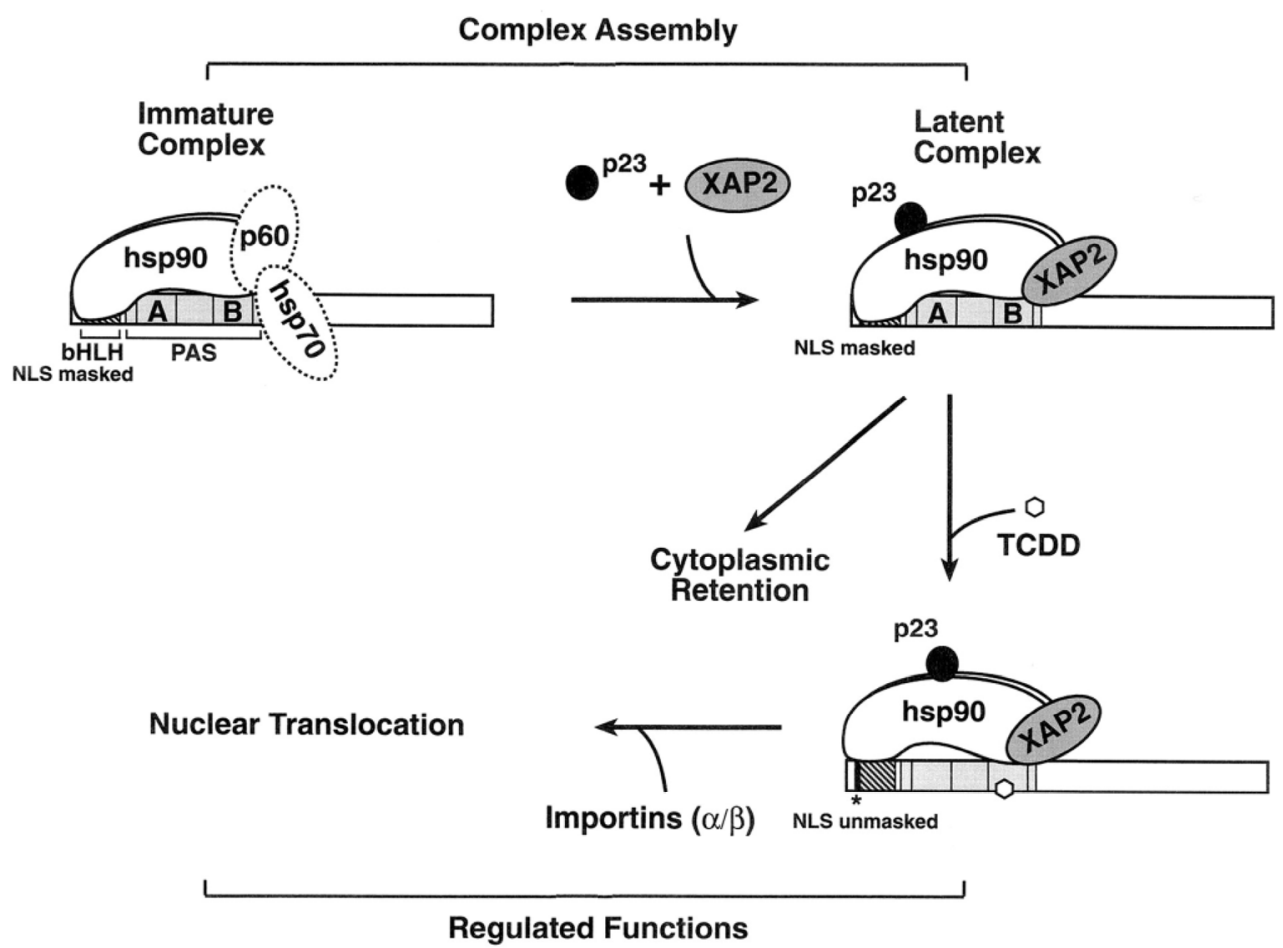

Figure 3. Activation of the AhR protein through formation of a multimeric complex

The presence of a HSP90 inhibitor, the geldanamycin (GA), has been demonstrated to interfere with the ligand-receptor binding, strongly suggesting that HSP90 plays an important role in regulating the intracellular traffic of AhR (Kazlauskas et al, 2001). The importin- $\alpha$, in turn, performs the function of acceptor of importin- $\beta$ that mediates the passage of the whole protein complex through the NPC. In fact, the dissociation of HSP90 from the multimeric complex ligand-receptor does not take place before the entire complex translocates to the nucleus (Heid, Pollenz, \& Swanson, 2000) (Figure 3).

In the nucleus, AhR dimerizes with its translocation factor ARNT (Reyes, Reisz-Porszasz, \& Hankinson, 1992; Probst, Reisz-Porszasz, Agbunag, Ong, \& Hankinson, 1993) and the dimerization induces the HSP90 release from the complex (Kazlauskas et al., 1999; McGuire, Whitelaw, Pongratz, Gustafsson, \& Poellinger, 1994). The heterodimer AhR/ARNT binds to specific regions on the DNA known as Dioxins Response Elements (DRE) or Xenobiotics Response Elements (XRE) (Matsushita, Sogawa, Ema, Yoshida, \& Fujii-Kuriyama, 1993; Watson \& Hankinson, 1992) located in the $5^{\prime}$ region of the AhR-responsive genes. The DRE/XRE are regulatory elements placed upstream of the transcription start site of dioxin-inducible genes (Poland \& Knutson, 1982). The binding of the AhR/ARNT heterodimer on the DRE/XRE elements involves the destruction of the nucleosome, the recruitment of transcription factors on the promoter region, and the subsequent mRNA synthesis. Currently, AhR and ARNT seem to directly bind to the general transcription factors. In mice, AhR/ARNT interact with the Transcription Factor IIF (TFIIF), while in humans AhR/ARNT interacts with both TFIIF and the transcription factor that specifically binds to sequences of DNA known as "TATA Box" (TATA-binding protein, TBP), which also represents the binding site of RNA polymerase II (Rowlands, McEwan, \& Gustafsson, 1996; Beischlag et al., 2002).

The mechanisms of signal transduction depending on transcriptional activation mediated by AhR-TCDD/ligand are not exactly the same among the different species and this diversity may affect the biological and toxicological interspecies responses. Overall, the main effectors involved in such signal transduction are:

- SRC1, coactivator 1 of the steroid receptor (also known as NCOA1 or coactivator of nuclear receptor 1), which is a protein endowed with intrinsic histone acetyltransferase activity and deputed to assist and support the activation of specific DNA sequences, after their specific binding with the estrogen receptor (ER);

- the p300 coactivator protein (also known as EP300 or E1A p300 binding protein), which actively participates in cell proliferation and differentiation processes. Mutations in EP300 gene have been observed at somatic level in some cancer types only: colorectal, stomach, pancreas, breast, and prostate carcinomas. 
In prostate cancer, presence of mutated p300 forms allows to predict the rate of the tumor growth and the metastatic spread of the disease;

- RIP140 or Nuclear Receptor-Interacting Protein 1 (NRIP1), which is another nuclear protein that modulates the transcriptional activity of a variety of factors (including the estrogen receptor) in heart, skeletal-muscle, and liver tissues, contributing to regulation of the metabolism of lipids and glucose.

Once the heterodimer AhR/ARNT with the entire battery of co-activators binds the regulatory regions containing the sequences DRE/XRE, the corresponding genes are transcriptionally activated and the synthesis of functionally distinct proteins begins. Among others, they include different enzymes that metabolize xenobiotics (mostly, belonging to the cytochrome P450 system, such as CYP1A1) (Watson \& Hankinson, 1992; Hoffer, Chang, \& Puga, 1996) as well as the AP-1 protein and the proto-oncogene products (c-Fos and c-Jun), which in turn act as well-known transcriptional regulators (Puga, Nebert, \& Carrier, 1992; Suh et al., 2002).

\subsection{AhR Polymorphism}

Genetic polymorphisms may modulate an individual's response to DNA-damaging agents derived from diet, life style, and environment. The most common genetic variation is represented by a single nucleotide polymorphism (SNP), occurring with a frequency of about 1 in 500-800 nucleotides. Several SNPs have been demonstrated to affect health outcomes caused by environmental exposure, being considered as important susceptibility factors. In the human genome, a mixture of high-penetrant/less-prevalent and low-penetrant/more-prevalent genetic variants can be detected. Experimental in vitro (human cell lines) and in vivo (animals) studies as well as epidemiological investigations conducted in populations accidentally exposed to dioxins, have revealed that the toxic responses are species-specific and may be related to AhR polymorphisms.

The AhR gene, encompassing about 50 kilobases at the genomic level, is thus expected to contain about 60-100 SNPs. Thus far, 120 SNPs have been identified within the coding regions of the AhR gene and included into the public database by the National Center for Biotechnology Information (NCBI) at www.ncbi.nlm.nih.gov/SNP. Distribution of SNPs within the open reading frame of the human AhR gene is presented in Table 1.

Table 1. Single-nucleotide polymorphisms (SNPs) in coding regions of the AhR gene

\begin{tabular}{|c|c|c|c|}
\hline Domain & Exon & $\begin{array}{c}\text { Total } \\
\text { number of } \\
\text { SNPs }\end{array}$ & SNP code \\
\hline UTR-5 & 1 & 1 & rs201368737 \\
\hline bHLH & 2 & 11 & $\begin{array}{l}\text { rs } 140254348, \text { rs368818841, rs } 371321791, \text { rs17779352, rs } 374827293, \text { rs41273054, } \\
\text { rs137949518, rs200664307, rs142412199, rs148360742, rs377294595 }\end{array}$ \\
\hline PAS & 3 & 7 & $\begin{array}{l}\text { rs } 141518984, \text { rs190138857, rs200324493, rs377724396, rs150911949, rs 199498192, } \\
\text { rs374791470 }\end{array}$ \\
\hline PAS & 4 & 6 & rs201276430, rs141667112, rs35966236, rs143848352, rs368194312, rs200257782 \\
\hline PAS & 5 & 6 & rs371996593, rs147237881, rs140821416, rs374428849, rs368615071, rs372336741 \\
\hline PAS & 6 & 6 & rs371991449, rs182857825, rs375293250, rs149809382, rs201831181, rs145760036 \\
\hline PAS-LBD & 7 & 5 & rs148672036, rs142158496, rs113673253, rs140380733, rs 374545462 \\
\hline PAS-LBD & 8 & 4 & rs201806511, rs376505668, rs190667274, rs181963856 \\
\hline PAS-LBD & 9 & 7 & $\begin{array}{c}\text { rs } 369460923, \text { rs370578969, rs200384399, rs145249237, rs146411430, rs 140788225, } \\
\text { rs374246059 }\end{array}$ \\
\hline TAD & 10 & 65 & 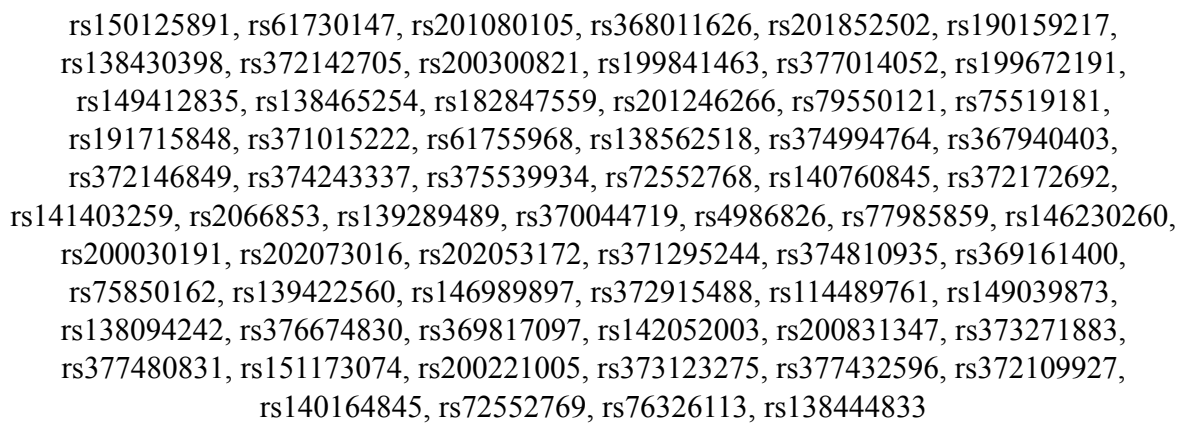 \\
\hline UTR-3' & 11 & 2 & rs372313569, rs146912085 \\
\hline
\end{tabular}


Considering the SNPs within introns as well as those located within the 5'- and 3'-untranslated regions the total amount of SNPS identified in the AhR gene is thus three-four times higher than expected.

In the human AhR gene, SNP variants occur predominantly in exon 10, a region that encodes a major portion of the transactivation domain of the receptor that is responsible for regulating expression of target genes (Harper, Wong, Lam, \& Okey, 2002). The other regions of the AhR gene comprehending functional SNPs are represented by exons 2 (which includes the bHLH domain), 4 (PAS domain), and 7 (PAS and LBD domains). Thus far, however, only a limited amount of genetic variants in AhR gene have been evaluated for exerting a functional role, leading to substantial differences in sensitivity to the biochemical and toxic effects of TCDD and related compounds (Table 2).

Table 2. Functionally investigated AhR single-nucleotide polymorphisms (SNPs)

\begin{tabular}{ccccc}
\hline SNP code & Codon & DNA position & Protein position & Designation \\
\hline rs7796976 & 5 '-UTR & c.-459 A $>$ G & - & $-459 A>G$ \\
rs17779352 & 44 & c.132 T $>$ C & p.Asn44Asn & N44N \\
rs41273054 & 50 & c.150 G $>$ A & p.Leu50Leu & L50L \\
rs35966236 & 132 & c.396 T $>$ C & p.Asp132Asp & D132D \\
rs61730147 & 398 & c.1192 C $>$ A & p.Arg398Arg & R398R \\
rs61755968 & 490 & c.1468 A $>\mathrm{G}$ & p.Met490Val & M490V \\
rs72552768 & 517 & c.1549 C $>$ T & p.Pro517Ser & P517S \\
rs2066853 & 554 & c.1661 G $>$ A & p.Arg554Lys & R554K \\
rs4986826 & 570 & c.1708 G $>$ A & p.Val570Ile & V570I \\
rs72552769 & 786 & c.2356 A $>\mathrm{G}$ & p.Met786Val & M786V \\
\hline
\end{tabular}

The most widely studied polymorphism is that at codon 554 (R554K); however, the interpretation of the phenotypic effects of this polymorphism is complicated. Harper and colleagues have shown that R554K exerts a strong effect on the AHR-mediated response by reducing the receptor function (Harper et al., 2002). The R554K has been reported to also segregate through linkage disequilibrium (such a genetic phenomenon is defined as the association between allelic variants that occurs more often than would be expected by chance) with other two SNPs in the same genomic region associated with transactivation of other genes in exon 10: P517S and V570I (Wong, Okey, \& Harper, 2001). Genotypes including each single polymorphism (at codon 554 or 570 or 571) as well as haplotypes combining all three polymorphisms (P517S-R554K-V570I) or two of them (R554K-V570I) failed to however exert a significant TCDD-dependent induction of CYP1A1 expression in in vitro experiments on cancer cell lines, even though these variants were found to maintain the ability to bind the TCDD as well as to interact with the aryl hydrocarbon response effectors (e.g. CYP1A1, CYP1A2, CYP1B1, ALDH3A1, NQO1 and UGT1A1) (Wong et al., 2001; Mandal, 2005). As a confirmation of this, none of such common polymorphisms (P517S, R544K, V570I, and R544K/V570I) was demonstrated to significantly enhance the TCDD-dependent regulation of CYP1A1 or CYP1B1 gene expression and activity in AhR-deficient human breast cancer cells transfected with the above-mentioned AhR variants (Celius \& Matthews, 2010). In this in vitro model, however, the lack of CYP1A1/B1 induction could be due to the occurrence of a marked ligand-independent activation of AhR target genes.

In addition to the polymorphisms in the transactivation domain of the human AhR, several SNPs have been reported in the 5'-flanking sequence, but none of these seems to modify receptor expression or function (Cauchi et al., 2001; Racky, Schmitz, Kauffmann, \& Schrenk, 2004). Recently, an intronic polymorphism in the AhR gene, IVS1+4640 G/A, has been associated with the risk of non-Hodgkin lymphoma in a case-control study also evaluating the level of exposure to organochlorines ( $\mathrm{Ng}$ et al., 2010). Although none of the investigated AhR variants seems to display an altered ability to modulate TCDD-dependent gene expression, all the same studies confirmed that the interaction of the TCDD ligand with AhR acts as a strong activator of transcription of the AhR target genes.

The functional effects of amino acid variations have been studied for only a few sites within the AHR protein. Therefore, additional strategies (i.e. gene-specific knockout in different cell lines or non-murine knockout animals) 
- as previously proposed (Porteus \& Carroll, 2005) should be employed in order to demonstrate the real functional impact of the different AhR gene variants. Nevertheless, additional molecular epidemiologic studies are awaited to effectively evaluate the impact of the different AhR polymorphisms on human health and cancer risk.

\section{Considerations and Perspectives on Environmental Pollution}

Recently, PCBs and dioxin-like PCBs were classified in Group 1 on the basis of extensive evidence of an AhR-mediated mechanism of carcinogenesis that is similar to that of TCDD as well as sufficient evidence of carcinogenicity in experimental animals (Lauby-Secretan et al., 2013). TCDD and its congeners have been released from industrial and incinerators over the last century, causing widespread contamination of food and significant toxic body burdens in nearly all living organisms. These molecules are extremely stable and spread rapidly through the environment, especially via the soil and water, inevitably polluting the food chain and accumulating in fatty tissues and milk as a result of their liposolubility (Wittsiepe et al., 2007; Todaka et al., 2011; Focant et al., 2013). Although tolerable daily intake (TDI) is set at 2 picograms $/ \mathrm{kg} / \mathrm{day}$ in Europe, it must be remembered that dioxins have a half-life in humans of 7 to 11 years, suggesting that this 'limit' does not safeguard against a potential accumulation within the body (Schecter et al., 2006; Thompson \& Anthony, 2008). The increased accumulation occurs in the fatty tissues and consequently in milk, potentially putting at risk younger generations. In fact, it can be assumed that a body accumulating Dioxins may have a permanently activated AhR protein, resulting in a continuous and uninterrupted state of immunosuppression (Ridolfi, Guidoboni, \& Ridolfi, 2010). Furthermore, the continuous activation of AhR could have an important role on inducing stem cells and, consequently, on development and progression of cancer (Gasiewicz, Singh, \& Bennett, 2014).

In the areas of greatest environmental pollution where, among other pollutants, high levels of Dioxins are found in soil, water, and food chain, a significant increase in the incidence of all types of cancer is recorded. Out of 23 Sites of Interesting Italian National (SIN) areas considered at environmental risk and followed by a tumor registry encompassing a total population of about 2 million individuals, the incidence of cancer increased by $9 \%$ in men and 7\% in women (Pirastu et al., 2011). In Taranto, site of the major steel plant in South Italy - where a disastrous pollution with accumulation of dioxins in soil and food chains has been documented over the years, data from the Istituto Superiore di Sanità (Rome) indicate an overall increase of all cancers of about 30\%, in comparison with incidence from other Italian Cancer Registries (Pirastu et al., 2013a).

While a documented serious increase in tumors caused by pollution and dioxins are thus observed, there are however workers and inhabitants of the same polluted areas that are less susceptible to cancer. This may lead one to speculate that there might be a different personal predisposition to action of pollutants, perhaps also linked to several metabolic capabilities of individuals to recruit, retain, and concentrate toxic substances.

Coming back to the possible actions of the binding AhR-TCDD, other hypotheses that could explain this differential susceptibility may be: $a$ ) a different effect of the binding capacity, on the basis of receptor polymorphisms; or $b$ ) an attenuation or elimination of the effectiveness of the binding due to a competition of endogenous or exogenous ligands with antagonist action. Our review relates to studies on human AhR polymorphisms and does not seem to indicate that there are individual genetic variants that may modulate the activity of the AhR receptor. While the AhR receptor is always strongly activated by the TCDD binding, data from literature do not indicate that human AHR polymorphisms may somehow interfere with the dioxin stimulation. One could argue that the high level of such an activation may be independent on the polymorphic changes occurring into the different functional tasks or domains of the AhR protein. Harper reports: "All current phenotyping methods can be confounded by factors other than genetic variation that alters the structure of the AHR itself" (Harper et al., 2002); therefore, we can assume that many other variables may play a role in determining both activation and function of the receptor. Overall, the different concentrations of TCDD in the plasma (or tissue), the duration of toxic stimuli (given the long half-lives of dioxin in the human body), the age of beginning of the stimulation, and/or the possible interference with antagonistic factors in the diet may all contribute to functionally modulate the AhR activity.

There are still too many questions awaiting for answers toward a full comprehension of the true role of the AhR protein in determining tumor disease in humans when activated by toxic pollutants. Further studies on polymorphisms of the gene regions mainly involved in the activation of AHR protein are warranted. Firstly, from the genetic point of view - with particular attention at the transactivation domain: frequency and prevalence of gene variants in different populations, in order to both identify those most characterizing the different groups of individuals and limit the number of them to be addressed to functional analyses. Then, from the biological point of view: preparation and analysis of the expression constructs in order to assess in vitro cellular models. It might be conceivable a case-control study on subjects living in heavily polluted sites compared to others who live in 
"healthier" geographical areas, evaluating the frequency of all AhR polymorphisms and the different susceptibility to cancer, as well as the possible interference of factors with antagonistic activity on the receptor.

\section{Conclusions}

The incidence of cancer continuously and progressively increases; such an increase seems to be particularly more evident in the most polluted geographical areas (Belpomme et al., 2007; Rossi et al., 2013; Pirastu et al., 2013b). The AhR protein represents the receptor which mostly binds toxic pollutants such as TCDD and its congeners; the high-affinity binding induces a strong agonistic activity of the receptor. Therefore, the activation of the TCDD-AhR axis is strongly involved in the process of carcinogenesis (Schecter et al., 2006; Feng et al., 2013). Many issues are yet to be determined about the manner in which individuals, although exposed to the same risk, are more or less susceptible to the development of cancer. On this regard, various factors should be encountered: the role of polymorphisms in specific regions of AhR, the plasma or tissue concentrations of Dioxins, the coexistence of AhR antagonists. Finally, the increasing incidence of childhood cancers as well as the onset of tumors in individuals at younger age are both particularly worrisome, especially in Italy. This may correlate with the findings recently reported in the literature about the accumulation of pollutants in the fetus through the umbilical cord and placenta (Soto \& Sonnenschein, 2010; Terracini \& Masera, 2013; Leino et al., 2013; Vizcaino, Grimalt, Fernández-Somoano, \& Tardon, 2014). An appeal is thus coming from several parts: we need new research work that may clarify too many obscure points on such issues (Christiani, 2011; Hanahan, 2014). Investigations in this field can be no longer delayed, and appear essential for leading a true primary prevention that protects the environment and the health of future generations.

\section{References}

Aguilera-Montilla, N., Chamorro, S., Nieto, C., Sánchez-Cabo, F., Dopazo, A., Fernández-Salguero, P. M., ... Corbí, A. L. (2013). Aryl hydrocarbon receptor contributes to MEK/ERK-dependent maintenance of the immature state of human dendritic cells. Blood, 121, e108-17. http://dx.doi.org/10.1182/blood-2012-07-4 45106

Allan, L. L., \& Sherr, D. H. (2005). Constitutive activation and environmental chemical induction of the aryl hydrocarbon receptor/transcription factor in activated human B lymphocytes. Mol Pharmacol, 67, 1740-50.

Ashida, H., Fukuda, I., Yamashita, T., \& Kanazawa, K. (2000). Flavones and flavonols at dietary levels inhibit a transformation of aryl hydrocarbon receptor induced by dioxin. FEBS Lett., 476, 213-7.

Ashida, H., Nishiumi, S., \& Fukuda, I. (2008). An update on the dietary ligands of the AhR. Expert Opin Drug Metab Toxicol., 4, 1429-47. http://dx.doi.org/10.1517/17425255.4.11.1429

Baan, R., Grosse, Y., Straif, K., Secretan, B., El Ghissassi, F., Bouvard, V., ... WHO International Agency for Research on Cancer Monograph Working Group. (2009). A review of human carcinogens--Part F: chemical agents and related occupations. Lancet Oncol., 10, 1143-4

Beischlag, T. V., Wang, S., Rose, D. W., Torchia, J., Reisz-Porszasz, S., Muhammad, K., ... Hankinson, O. (2002). Recruitment of the NCoA/SRC-1/p160 family of transcriptional coactivators by the Aryl Hydrocarbon Receptor/Aryl Hydrocarbon Receptor Nuclear Translocator complex. Mol. Cell. Biol., 22, 4319-4333.

Belpomme, D., Irigaray, P., Sasco, A. J., Newby, J. A., Howard, V., Clapp, R., \& Hardell, L. (2007). The growing incidence of cancer: role of lifestyle and screening detection. Int J Oncol., 30, 1037-49.

Bohonowych, J. E., \& Denison, M. S. (2007). Persistent binding of ligands to the aryl hydrocarbon receptor. Toxicol Sci., 98, 99-109

Casado, F. L., Singh, K. P., \& Gasiewicz, T. A. (2011). Aryl hydrocarbon receptor activation in hematopoietic stem/progenitor cells alters cell function and pathway-specific gene modulation reflecting changes in cellular trafficking and migration. Mol Pharmacol., 80, 673-82. http://dx.doi.org/10.1124/mol.111.071381

Cauchi, S., Stucker, I., Solas, C., Laurent-Puig, P., Cenee, S., Hemon, D., ... Massaad-Massade, L. (2001). Polymorphisms of human aryl hydrocarbon receptor (AhR) gene in a French population: relationship with CYP1A1 inducibility and lung cancer. Carcinogenesis, 22, 1819-24

Celius, T., \& Matthews, J. (2010). Functional analysis of six aryl hydrocarbon receptor variants in human breast cancer and mouse hepatoma cell lines. Toxicology, 277, 59-65. http://dx.doi.org/10.1016/j.tox.2010.08.015

Christiani, D. C. (2011). Combating environmental causes of cancer. N Engl J Med., 364, 791-3. http://dx.doi.org/ 10.1056/NEJMp1006634 
Contador-Troca, M., Alvarez-Barrientos, A., Barrasa, E., Rico-Leo, E. M., Catalina-Fernández, I., Menacho-Márquez, M., ... Fernández-Salguero, P. M. (2013). The dioxin receptor has tumor suppressor activity in melanoma growth and metastasis. Carcinogenesis, 34, 2683-93. http://dx.doi.org/10.1093/carcin/ bgt 248

Coumailleau, P., Poellinger, L., Gustafsson, J. A., \& Whitelaw, M. L. (1995). Definition of a minimal domain of the di- oxin receptor that is associated with hsp90 and maintains wild type ligand binding affinity and specificity. J. Biol. Chem., 270, 25291-25300

Cox, M. B., \& Miller, C. A. (2004). Cooperation of heat shock protein 90 and p23 in aryl hydrocarbon receptor signaling. Cell Stress Chaperones, 9, 4-20

Denis, M., Cuthill, S., Wikström, A. C., Poellinger, L., \& Gustafssonm J. (1998). Association of the dioxin receptor with the Mr 90,000 heat shock protein: a structural kinship with the glucocorticoid receptor. Biochem. Biophys. Res. Commun., 155, 801-817.

Denison, M. S., \& Nagy, S. R. (2003). Activation of the aryl hydrocarbon receptor by structurally diverse exogenous and endogenous chemicals. Annu. Rev. Pharmacol. Toxicol., 43, 309-34

Di Natale, B. C., Schroeder, J. C., \& Perdew, G. H. (2011). Ah receptor antagonism inhibits constitutive and cytokine inducible IL6 production in head and neck tumor cell lines. Mol Carcinog., 50, 173-83. http://dx.doi. org/10.1002/mc.20702

Dietrich, C., \& Kaina, B. (2010). The aryl hydrocarbon receptor (AhR) in the regulation of cell-cell contact and tumor growth. Carcinogenesis, 31, 1319-28. http://dx.doi.org/10.1093/carcin/bgq028

Elferink, C. J. (2003). Aryl hydrocarbon receptor-mediated cell cycle control. Prog Cell Cycle Res., 5, 261-7

Ema, M., Matsushita, N., Sogawa, K., Ariyama, T., Inazawa, J., Nemoto, T., ... Fujii-Kuriyama, Y. (1994). Human arylhydrocarbon receptor: functional expression and chromosomal assignment to 7p21. J. Biochem., $116,845-851$

Ema, M., Sogawa, K., Watanabe, N., Chujoh, Y., Matsushita, N., Gotoh, O., ... Fujii-Kuriyama, Y. (1992). cDNA cloning and structure of mouse putative Ah receptor. Biochem. Biophys. Res. Commun., 184, 246-253

Esser, C., Rannug, A., \& Stockinger, B. (2009). The aryl hydrocarbon receptor in immunity. Trends Immunol., 30, 447-54. http://dx.doi.org/10.1016/j.it.2009.06.005

Falahatpisheh, M. H., \& Ramos, K. S. (2003). Ligand-activated Ahr signaling leads to disruption of nephrogenesis and altered Wilms' tumor suppressor mRNA splicing. Oncogene, 22(14), 2160-71.

Feng, S., Cao, Z., \& Wang, X. (2013). Role of aryl hydrocarbon receptor in cancer. Biochim Biophys Acta, 1836, 197-210. http://dx.doi.org/10.1016/j.bbcan.2013.05.001

Focant, J. F., Fréry, N., Bidondo, M. L., Eppe, G., Scholl, G., Saoudi, A., ... Vandentorren, S. (2013). Levels of polychlorinated dibenzo-p-dioxins, polychlorinated dibenzofurans and polychlorinated biphenyls in human milk from different regions of France. Sci Total Environ., 453, 155-62. http://dx.doi.org/10.1016/j.scitotenv. 2013.02.057

Funatake, C. J., Marshall, N. B., Steppan, L. B., Mourich, D. V., \& Kerkvliet, N. I. (2005). Cutting edge: activation of the aryl hydrocarbon receptor by 2,3,7,8-tetrachlorodibenzo-p-dioxin generates a population of CD4+ CD25+ cells with characteristics of regulatory T cells. J Immunol., 175, 4184-8

Gandhi, R., Kumar, D., Burns, E. J., Nadeau, M., Dake, B., Laroni, A., ... Quintana, F. J. (2010). Activation of the aryl hydrocarbon receptor induces human type 1 regulatory T cell-like and Foxp3(+) regulatory T cells. Nat Immunol., 11, 846-53. http://dx.doi.org/10.1038/ni.1915.

Gasiewicz, T. A., Singh, K. P., \& Bennett, J. A. (2014). The Ah receptor in stem cell cycling, regulation, and quiescence. Ann N Y Acad Sci., 1310, 44-50. http://dx.doi.org/10.1111/nyas.12361

Glinka, Y., Mohammed, N., Subramaniam, V., Jothy, S., \& Prud'homme, G. J. (2012). Neuropilin-1 is expressed by breast cancer stem-like cells and is linked to NF- $\kappa \mathrm{B}$ activation and tumor sphere formation. Biochem Biophys Res Commun., 425, 775-80. http://dx.doi.org/10.1016/j.bbrc.2012.07.151.

Goryo, K., Suzuki, A., Del Carpio, C. A., Siizaki, K., Kuriyama, E., Mikami, Y., ... Sogawa K. (2007). Identification of amino acid residues in the Ah receptor involved in ligand binding. Biochem. Biophys. Res. Commun., 354, 396-402 
Gu, Y. Z., Hogenesch, J. B., \& Bradfield, C. A. (2000). The PAS superfamily: sensors of environmental and developmental signals. Ann. Rev. Pharmacol. Toxicol., 40, 519-561

Hahn, M. E. (2002). Aryl hydrocarbon receptors: diversity and evolution. Chem Biol Interact., 141, 131-60

Hanahan, D. (2014). Rethinking the war on cancer. Lancet., 383, 558-63. http://dx.doi.org/10.1016/S0140-6736 (13)62226-6

Harper, P. A., Wong, J. M., Lam, M. S., \& Okey, A. B. (2002). Polymorphisms in the human AH receptor. Chem Biol Interact., 141, 161-87

Heid, S. E., Pollenz, R. S., \& Swanson, H. I. (2000). Role of heat shock protein 90 in mediating agonist-induced activation of the aryl hydrocarbon receptor. Molecular pharmacology, 57, 82-92

Hockings, J. K., Thorne, P. A., Kemp, M. Q., Morgan, S. S., Selmin, O., \& Romagnolo, D. F. (2006). The ligand status of the aromatic hydrocarbon receptor modulates transcriptional activation of BRCA-1 promoter by estrogen. Cancer Res., 66, 2224-32

Hoffer, A., Chang, C. Y., \& Puga, A. (1996). Dioxin induces transcription of fos and jun genes by Ah receptor-dependent and -independent pathways. Toxicol. Appl. Pharmacol., 141, 238-247

Ito, T., Inouye, K., Fujimaki, H., Tohyama, C., \& Nohara, K. (2002). Mechanism of TCDD-induced suppression of antibody production: effect on $\mathrm{T}$ cell-derived cytokine production in the primary immune reaction of mice. Toxicol Sci., 70, 46-54

John, K., Lahoti, T. S., Wagner, K., Hughes, J. M., \& Perdew, G. H. (2013). The Ah receptor regulates growth factor expression in head and neck squamous cell carcinoma cell lines. Mol Carcinog. http://dx.doi.org/ $10.1002 / \mathrm{mc} .22032$

Kazlauskas, A., Poellinger, L., \& Pongratz, I. (1999). Evidence that the co-chaperone p23 regulates ligand responsiveness of the dioxin (Aryl hydrocarbon) receptor. J. Biol. Chem., 274, 13519-24

Kazlauskas, A., Sundstrom, S., Poellinger, L., \& Pongratz, I. (2001). The HSP90 chaperone complex regulates intracellular localization of the dioxin receptor. Mol. Cell. Biol., 21, 2594-2607

Kerkvliet, N. I. (2002). Recent advances in understanding the mechanisms of TCDD immunotoxicity. Int Immunopharmacol., 2, 277-91

Kumar, M. B., Ramadoss, P., Reen, R. K., Vanden Heuvel, J. P., \& Perdew, G. H. (2001). The Q-rich subdomain of the human Ah receptor transactivation domain is required for dioxin-mediated transcriptional activity. $J$. Biol. Chem., 276, 42302-42310

Laiosa, M. D., Wyman, A., Murante, F. G., Fiore, N. C., Staples, J. E., \& Gasiewicz, T. A. (2003). Cell proliferation arrest within intrathymic lymphocyte progenitor cells causes thymic atrophy mediated by the aryl hydrocarbon receptor. J Immunol., 171, 4582-91

Lauby-Secretan, B., Loomis, D., Grosse, Y., El Ghissassi, F., Bouvard, V., Benbrahim-Tallaa, L., ... International Agency for Research on Cancer Monograph Working Group IARC. (2013). Carcinogenicity of polychlorinated biphenyls and polybrominated biphenyls. Lancet Oncol., 14, 287-8. http://dx.doi.org/10. 1016/S 1470-2045(13)70104-9

Laupeze, B., Amiot, L., Sparfel, L., Le Ferrec, E., Fauchet, R., \& Fardel, O. (2002). Polycyclic aromatic hydrocarbons affect functional differentiation and maturation of human monocyte-derived dendritic cells. $J$ Immunol., 168, 2652-8

Le Beau, M. M., Carver, L. A., Espinosa, R., Schmidt, J. V., \& Bradfleld, C. A. (1994). Chromosomal localization of the human AHR locus encoding the structural gene for the Ah receptor to 7p21-p15. Cytogenet. Cell Genet., $66,72-176$

Lee, J. A., Hwang, J. A., Sung, H. N., Jeon, C. H., Gill, B. C., \& Youn, H. J. (2007). 2,3,7,8-tetrachlorodibenzo-p-dioxin modulates functional differentiation of mouse bone marrow-derived dendritic cells: downregulation of RelB by 2,3,7,8-tetrachlorodibenzo-p-dioxin. Toxicol Lett., 173, 31-40

Leino, O., Kiviranta, H., Karjalainen, A. K., Kronberg-Kippila, C., Sinkko, H., \& Larsen, E. H. (2013). Pollutant concentrations in placenta. Food Chem Toxicol., 54, 59-69. http://dx.doi.org/10.1016/j.fct.2011.10.058

Mandal, P. K. (2005). Dioxin: a review of its environmental effects and its aryl hydrocarbon receptor biology. $J$. Comp. Physiol. B., 175, 221-30. 
Marlowe, J. L., \& Puga, A. (2005). Aryl hydrocarbon receptor, cell cycle regulation, toxicity, and tumorigenesis. $J$ Cell Biochem., 96, 1174-84

Matsushita, N., Sogawa, K., Ema, M., Yoshida, A., \& Fujii-Kuriyama, Y. (1993). A factor binding to the Xenobiotic Responsive Element (XRE) of P-4501A1 gene consists of at least two Helix-Loop-Helix proteins, Ah Receptor and Arnt. J. Biol. Chem., 268, 21002-6

McGuire, J., Whitelaw, M. L., Pongratz, I., Gustafsson, J. A., \& Poellinger, L. (1994). A cellular factor stimulates ligand-dependent release of hsp90 from the basic helix-loop-helix dioxin receptor. Mol. Cell. Biol., 14, 2438-46

Meyer, B. K., Pray-Grant, M. G., Vanden Heuvel, J. P., \& Perdew, G. H. (1998). Hepatitis B virus X-associated protein 2 is a subunit of the unliganded aryl hydrocarbon receptor core complex and exhibits transcriptional enhancer activity. Mol. Cell. Biol., 18, 978-988

Micka, J., Milatovich, A., Menon, A., Grabowski, G. A., Puga, A., \& Nebert, D. W. (1997). Human Ah receptor (AHR) gene: localization to $7 \mathrm{p} 15$ and suggestive correlation of polymorphism with CYP1A1 inducibility. Pharmacogenetics, 7, 95-101

Mimura, J., \& Fujii-Kuriyama, Y. (2003). Functional role of AhR in the expression of toxic effects by TCDD. Biochim Biophys Acta, 1619, 263-8

Mukai, R., Shirai, Y., Saito, N., Fukuda, I., Nishiumi, S., Yoshida, K., \& Ashida, H. (2010). Suppression mechanisms of flavonoids on aryl hydrocarbon receptor-mediated signal transduction. Arch Biochem Biophys, 501, 134-41. http://dx.doi.org/10.1016/j.abb.2010.05.002

Ng, C. H., Janoo-Gilani, R., Sipahimalani, P., Gallagher, R. P., Gascoyne, R. D., Connors, J. M., ... Spinelli, J. J. (2010). Interaction between organochlorines and the AHR gene, and risk of non-Hodgkin lymphoma. Cancer Causes Control, 21, 11-22. http://dx.doi.org/10.1007/s10552-009-9429-5

Nishiumi, S., Hosokawa, K., Mukai, R., Fukuda, I., Hishida, A., Iida, O., ... Ashida, H. (2006). Screening of indigenous plants from Japan for modulating effects on transformation of the aryl hydrocarbon receptor. Asian Pac J Cancer Prev., 7, 208-20

Nishiumi, S., Miyamoto, S., Kawabata, K., Ohnishi, K., Mukai, R., Murakami, A., ... Terao, J. (2011). Dietary flavonoids as cancer-preventive and therapeutic biofactors. Front Biosci, 3, 1332-62

Papoutsis, A. J., Borg, J. L., Selmin, O. I., \& Romagnolo, D. F. (2012). BRCA-1 promoter hypermethylation and silencing induced by the aromatic hydrocarbon receptor-ligand TCDD are prevented by resveratrol in MCF-7 cells. J Nutr Biochem., 23, 1324-32. http://dx.doi.org/10.1016/j.jnutbio.2011.08.001

Perdew, G. H. (1998). Association of the Ah receptor with the 90-kDa heat shock protein. J. Biol. Chem., 263, 13802-13805

Pirastu, R., Ancona, C., Iavarone, I., Mitis, F., Zona, A., \& Comba, P. (2011). SENTIERI Project. Mortality study of residents in Italian polluted sites: results. Epidemiologia e Prevenzione 35(supp14), 1-204

Pirastu, R., Comba, P., Iavarone, I., Zona, A., Conti, S., Minelli, G., ... Biggeri, A. (2013a). Environment and health in contaminated sites: the case of Taranto, Italy. J Environ Public Health., 753719. http://dx.doi.org/10. $1155 / 2013 / 753719$

Pirastu, R., Pasetto, R., Zona, A., Ancona, C., Iavarone, I., Martuzzi, M., \& Comba, P. (2013b).The health profile of populations living in contaminated sites: SENTIERI approach. J Environ Public Health., 939267. http://dx.doi.org/10.1155/2013/939267

Poland, A., \& Knutson, C. (1982). 2,3,7,8-Tetrachlorodibenzo-p-dioxin and related halogenated aromatic hydrocarbons: Examination of the mechanism of toxicity. Annu. Rev. Pharmacol. Toxicol., 22, 517-554

Porteus, M. H., \& Carroll, D. (2005). Gene targeting using zinc finger nucleases. Nature Biotechnol., 23, 967-973

Probst, M. R., Reisz-Porszasz, S., Agbunag, R. V., Ong, M. S., \& Hankinson, O. (1993). Role of the aryl hydrocarbon receptor nuclear trans locator protein in aryl hydrocarbon (dioxin) receptor action. Mol. Pharmacol., 44, 511-518

Prud'homme, G. J., Glinka, Y., Toulina, A., Ace, O., Subramaniam, V., \& Jothy, S. (2010). Breast cancer stem-like cells are inhibited by a non-toxic aryl hydrocarbon receptor agonist. PLoS One., 5, e13831. http://dx.doi.org/10.1371/journal.pone.0013831 
Puga, A., Nebert, D. W., \& Carrier, F. (1992). Dioxin induces expression of c-fos and c-jun proto-oncogenes and a large increase in transcription factor AP-1. DNA Cell Biol., 11, 269-281

Quintana, F. J. (2013). The aryl hydrocarbon receptor: a molecular pathway for the environmental control of the immune response. Immunology., 138, 183-9. http://dx.doi.org/10.1111/imm.12046

Quintana, F. J., Basso, A. S., Iglesias, A. H., Korn, T., Farez, M. F., Bettelli, E., ... Weiner, H. L. (2008). Control of $\mathrm{T}(\mathrm{reg})$ and $\mathrm{T}(\mathrm{H}) 17$ cell differentiation by the aryl hydrocarbon receptor. Nature, 453, 65-71. http://dx.doi.org/10.1038/nature06880

Racky, J., Schmitz, H. J., Kauffmann, H. M., \& Schrenk, D. (2004). Single nucleotide polymorphism analysis and functional characterization of the human Ah receptor (AhR) gene promoter. Arch. Biochem. Biophys., 421, 91-98

Reyes, H., Reisz-Porszasz, S., \& Hankinson, O. (1992). Identification of the Ah receptor nuclear translocator protein (Arnt) as a component of the DNA binding form of the Ah receptor. Science, 256, 1193-95

Ridolfi, R., Guidoboni, M., \& Ridolfi, L. (2010). Cancer immunoediting and dioxin-activating aryl hydrocarbon receptor: a missing link in the shift towards tumor immunoescape? Journal of Nucleic Acids Investigation (JNAI), 1, e6. http://dx.doi.org/10.4081/jnai.2010.e6

Rossi, M., Bosetti, C., Negri, E., Lagiou, P., \& La Vecchia, C. (2010). Flavonoids, proanthocyanidins, and cancer risk: a network of case-control studies from Italy. Nutr Cancer, 62, 871-7. http://dx.doi.org/10.1080/0163 5581.2010 .509534

Rossi, S., Crocetti, E., Capocaccia, R., Gatta, G., \& AIRTUM Working Group. (2013). Estimates of cancer burden in Italy. Tumori., 99, 416-24. http://dx.doi.org/10.1700/1334.14807

Rowlands, J. C., McEwan, I. J., \& Gustafsson, J. A. (1996). Trans-activation by the human aryl hydrocarbon receptor and aryl hydrocarbon receptor nuclear translocator proteins: direct interactions with basal transcription factors. Mol. Pharmacol., 50, 538-548

Savouret, J. F., Antenos, M., Quesne, M., Xu, J., Milgrom, E., \& Casper, R. F. (2001). 7-ketocholesterol is an endogenous modulator for the arylhydrocarbon receptor. J. Biol. Chem., 276, 3054-9

Schecter, A., Birnbaum, L., Ryan, J. J., \& Constable, J. D. (2006). Dioxins: an overview. Environ Res., 101, 419-28

Schecter, A., Startin, J., Wright, C., Kelly, M., Päpke, O., Lis, A., ... Olson, J. R. (1994). Congener-specific levels of dioxins and dibenzofurans in US food and estimated daily dioxin toxic equivalent intake. Env Health Perspect., 102, 962-6

Sherr, D. H., \& Monti, S. (2013). The role of the aryl hydrocarbon receptor in normal and malignant B cell development. Semin Immunopathol., 35, 705-16. http://dx.doi.org/10.1007/s00281-013-0390-8

Soto, A. M., \& Sonnenschein, C. (2010). Environmental causes of cancer: endocrine disruptors as carcinogens. Nat Rev Endocrinol., 6, 363-70. http://dx.doi.org/10.1038/nrendo.2010.87

Stevens, E. A., Mezrich, J. D., \& Bradfield, C. A. (2009). The aryl hydrocarbon receptor: a perspective on potential roles in the immune system. Immunology, 127, 299-311. http://dx.doi.org/10.1111/j.1365-2567. 2009.03054.x

Stockinger, B. (2009). Beyond toxicity: aryl hydrocarbon receptor-mediated functions in the immune system. $J$ Biol., 8, 61. http://dx.doi.org/10.1186/jbiol170

Suh, J., Jeon, Y. J., Kim, H. M., Kang, J. S., Kaminski, N. E., \& Yang, K. H. (2002). Aryl hydrocarbon receptor-dependent inhibition of AP-1 activity by 2,3,7,8-tetrachlorodibenzo-p-dioxin in activated B cells. Toxicol. Appl. Pharmacol., 181, 116-123

Temchura, V. V., Frericks, M., Nacken, W., \& Esser, C. (2005). Role of the aryl hydrocarbon receptor in thymocyte emigration in vivo. Eur J Immunol, 35, 2738-47

Terracini, B., \& Masera, G. (2013). Childhood cancer incidence and the fourth side of the Maccacaro's rectangle. Epidemiol Prev, 37, 102-104

Thompson, J., \& Anthony, H. (2008). The Health Effects of Waste Incinerators. 4th Report of the British Society for Ecological Medicine (2nd ed.).

Todaka, T., Hirakawa, H., Kajiwara, J., Onozuka, D., Sasaki, S., Miyashita, C., ... Furue, M. (2011). Concentrations of polychlorinated dibenzo-p-dioxins, polychlorinated dibenzofurans, and polychlorinated 
biphenyls in blood and breast milk collected from pregnant women in Sapporo City, Japan. Chemosphere, 85, 1694-700. http://dx.doi.org/10.1016/j.chemosphere.2011.09.014

Tomatis, L. (2002). The IARC monographs program: changing attitudes towards public health. Int J Occup Environ Health, 8, 144-52

Tomkiewicz, C., Herry, L., Bui, L. C., Métayer, C., Bourdeloux, M., ... Coumoul, X. (2013). The aryl hydrocarbon receptor regulates focal adhesion sites through a non-genomic FAK/Src pathway. Oncogene, 32, 1811-20. http://dx.doi.org/10.1038/onc.2012.197.

Tsay, J. J., Tchou-Wong, K. M., Greenberg, A. K., Pass, H., \& Rom, W. N. (2013). Aryl hydrocarbon receptor and lung cancer. Anticancer Res., 33, 1247-56.

Veldhoen, M., Hirota, K., Westendorf, A. M., Buer, J., Dumoutier, L., Renauld, J. C., \& Stockinger, B. (2008). The aryl hydrocarbon receptor links TH17-cell-mediated autoimmunity to environmental toxins. Nature, 453, 106-9. doi: 10.1038/nature06881

Vizcaino, E., Grimalt, J. O., Fernández-Somoano, A., \& Tardon, A. (2014). Transport of persistent organic pollutants across the human placenta. Environ Int., 65, 107-15. http://dx.doi.org/10.1016/j.envint.2 014.01 .004

Vogel, C. F., Wu, D., Goth, S. R., Baek, J., Lollies, A., Domhardt, R., ... Pessah, I. N. (2013). Aryl hydrocarbon receptor signaling regulates $\mathrm{NF}-\kappa \mathrm{B}$ RelB activation during dendritic-cell differentiation. Immunol Cell Biol., 91, 568-75. http://dx.doi.org/10.1038/icb.2013.43

Vorderstrasse, B. A., \& Kerkvliet, N. I. (2001). 2,3,7,8-tetrachlorodibenzo-p-dioxin affects the number and function of murine splenic dendritic cells and their expression of accessory molecules. Toxicol Appl Pharmacol., 171, 117-25

Vorderstrasse, B. A., Dearstyne, E. A., \& Kerkvliet, N. I. (2003). Influence of 2,3,7,8-tetrachlorodibenzo-p-dioxin on the antigen-presenting activity of dendritic cells. Toxicol Sci., 72, 103-12

Watson, A. J., \& Hankinson, O. (1992). Dioxin- and Ah receptor-dependent protein binding to xenobiotic responsive elements and G-rich DNA studied by in vivo footprinting. J. Biol. Chem., 267, 6874-6878

Wittsiepe, J., Fürst, P., Schrey, P., Lemm, F., Kraft, M., Eberwein, G., ... Wilhelm, M. (2007). PCDD/F and dioxin-like PCB in human blood and milk from German mothers. Chemosphere, 67, S286-94

Wong, J. M., Okey, A. B., \& Harper, P. A. (2001). Human aryl hydrocarbon receptor polymorphisms that result in loss of CYP1A1 induction, Biochem. Biophys. Res. Commun., 288, 990-996.

Note

bHLH, basic helix-loop-helix domain; hsp90, 90-kDa heath shock protein; NLS, nuclear localization signal sequence; PAS, Per/Arnt/Sim domain; LBD, ligand-binding domain; TAD, transactivation domain; UTR, untranslated region; XAP2, hepatitis B virus X-associated protein 2.

\section{Copyrights}

Copyright for this article is retained by the author(s), with first publication rights granted to the journal.

This is an open-access article distributed under the terms and conditions of the Creative Commons Attribution license (http://creativecommons.org/licenses/by/3.0/). 